\title{
The relationship between social support and functional capacity in elderly persons with cognitive alterations ${ }^{1}$
}

\author{
Tábatta Renata Pereira de Brito ${ }^{2}$ \\ Sofia Cristina lost Pavarini ${ }^{3}$
}

\begin{abstract}
The objective of this study was to identify the relationship between social support and the functional capacity of elderly persons with cognitive alterations. It is a descriptive, cross-sectional and quantitative study. The subjects were 101 elderly persons registered in Family Health Centers whose performance in the Mini-Exam for Mental Status was below a certain specified level in a previous study. The Medical Outcomes Study questionnaire, Katz Index and Pfeffer Questionnaire were applied. The dimensions of material, affective, emotional, informational and positive social interaction support resulted in an average final score of 74.32 points, indicating a better level of material and affective support in relation to the other dimensions of support. There was a statistically significant correlation between emotional support and the Katz Index. Knowledge about this relationship favors the development of a nursing care pathway for the elderly which is capable of maintaining their functional capacity and ensuring satisfactory social relations.
\end{abstract}

Descriptors: Aged; Social Support; Activities of Daily Living; Cognition Disorders.

\footnotetext{
${ }_{1}$ Paper extracted from Master's Thesis "Idosos com alterações cognitivas: estudando o apoio social em diferentes contextos de vulnerabilidade social", presented to Universidade Federal de São Carlos, Brazil.

2 Doctoral student, Escola de Enfermagem, Universidade de São Paulo, Brazil.

${ }^{3}$ PhD, Associate Professor, Universidade Federal de São Carlos, Brazil.
} 


\section{Relação entre apoio social e capacidade funcional de idosos com alterações cognitivas}

O objetivo deste trabalho foi identificar a relação entre o apoio social e a capacidade funcional de idosos com alterações cognitivas. Trata-se de estudo descritivo, transversal, quantitativo. Os sujeitos foram 101 idosos cadastrados em Unidades de Saúde da Família que apresentaram desempenho no Mini Exame do Estado Mental abaixo da nota de corte em estudo anterior. Aplicaram-se o Medical Outcomes Study, Índice de Katz e Questionário de Atividades Funcionais de Pfeffer. As dimensões de apoio material, afetivo, emocional, de informação e de interação social positiva resultaram em um escore final médio de 74,43 pontos, indicando melhor nível de apoio material e afetivo em relação às demais dimensões de apoio. Houve correlação estatisticamente significativa entre o apoio emocional e o Índice de Katz. O conhecimento dessa relação favorece o desenvolvimento de uma linha de cuidado em enfermagem ao idoso capaz de manter sua capacidade funcional e garantir relações sociais satisfatórias.

Descritores: Idoso; Apoio Social; Atividades Cotidianas; Transtornos Cognitivos.

\section{Relación entre apoyo social y capacidad funcional de los mayores con los cambios cognitivos}

El objetivo de este estudio fue identificar la relación entre el apoyo social y funcionalidad de personas mayores con deterioro cognitivo. Es un estudio descriptivo, transversal y cuantitativo. Los sujetos fueron 101 mayores inscritos en Unidades de Salud Familiar que mostro rendimiento en Mini Examen del Estado Mental por debajo del umbral en estudio anterior. Se aplicó Medical Outcomes Study, Índice Katz y cuestionario Pfeffer. Las dimensiones del apoyo material, afectivo, emocional, interacción social positiva y de información dio lugar a una puntuación media final de 74,43 puntos, lo que indica mayor nivel de apoyo material y afectivo con relación a otras dimensiones de apoyo. Hubo una correlación estadísticamente significativa entre apoyo emocional e índice de Katz. El conocimiento de esta relación favorece el desarrollo de una línea de atención de enfermería a los mayores, capaz de mantener su capacidad funcional, y garantizar relaciones sociales satisfactorias.

Descriptores: Anciano; Apoyo Social; Actividades Cotidianas; Trastornos del Conocimiento.

\section{Introduction}

The entire world is aging, and the increase in the numbers of the elderly in the population has translated into a greater number of long-term problems, both for individuals and for society. For the individual in particular, aging - allied with the presence of multiple chronic illnesses - is related directly with greater functional incapacity among the elderly. Moreover, with the increase in life expectancy, it is expected that the number of elderly with cognitive alterations will increase continuously ${ }^{(1-2)}$.
Functional capacity in the elderly is measured by their ability to carry out, independently, their routine activities, also called the activities of daily living (ADL). Such activities are didactically divided into basic activities (BADLs) and instrumental activities (IADLs). The BADLs are related to self-care and the IADLs refer to those activities related to living independently in the community(3-4). Being independent in carrying out activities of daily living is of great importance in people's lives, as it involves questions of an emotional, physical 
and social nature. Dependency constitutes a significant risk factor for mortality in the elderly population, being more relevant than the illnesses themselves which lead to it. Loss, in instrumental activities of daily living, contributes to greater estrangement from one's social surroundings and consequently to a tendency to be isolated in one's residence, while basic activities of daily living are associated with the question of survival(5).

In relation to cognitive alterations, normal aging itself presents a gradual decline of functions such as language, perception, motor skills and executive functions, with memory loss standing out most in the population in general, as this compromises small tasks relating to the activities of daily living. The biggest concern is in the possibility of memory loss representing the existence or future possibility of dementia(6). Moreover, the maintenance of cognition is an important determinant for quality of life and life expectancy in old age, as cognitive decline is associated with personal discomfort, loss of autonomy and increase of social $\operatorname{costs}^{(7)}$.

Thus, the process of aging being multidimensional and singular, the need may be observed for the carrying out of studies which make understanding of the elderly possible - not only concerning the physical aspect of cognitive decline and functional capacity, but also of other elements considered, in particular the human and social aspects $^{(6)}$.

This being so, it is assumed that the base pathologies are of internal development, but that they are also influenced by the social relationships established between individuals in social networks ${ }^{(8)}$.

The social support network represents a web of social relationships which each person maintains, including closer relationships (such as with family members and close friends) and more formal relationships (other individuals and groups). Despite much study, there is no agreement between researchers concerning the concept of social support. One way of explaining 'social support' is that it is a function of social networks. It is considered the principal function and, also, the developer of the construction of the social networks(9). The social support refers to either the functional or qualitative dimension of the social network, and is a system formed by formal and informal relationships through which an individual receives information and emotional, affective, and material help, and establishes positive social interaction ${ }^{(10)}$.
Among the studies which point out the relationship between elderly people's health and their social relationships, the majority of authors emphasize that satisfactory social relationships seem to promote better health conditions, but the mechanisms through which these effects are exercised are still not totally understood. Social support may protect individuals from the pathogenic effects of stressing events, as much as it may positively affect people's health by providing resources (economic and material help and information), better access to health care and regulation of living habits ${ }^{(11)}$.

Studies have indicated the satisfactory social support is a protective factor in functional incapacity and cognitive compromise in the elderly ${ }^{(12-14)}$. Social support helps the elderly to keep themselves autonomous and independent in their family and socio-cultural context, which is fundamental for their cognitive functions and for their psychological well-being(12-14).

Taking into account that elderly persons with cognitive alterations present greater difficulty in performing activities of daily living, and suffer a gradual degradation of their behavioral and social abilities, this present study may contribute to knowledge in the area of Nursing, as it promotes the adequate structuring of the attention to this population, which requires direct nursing care. Furthermore, it may contribute through the implantation of a family care pathway, in which the establishing of satisfactory social relationships can contribute to independence in carrying out activities of daily living, thus improving the health conditions of the elderly with cognitive alterations.

The objective of this work, therefore, was to identify the relationship between social support and the functional capacity of elderly persons with cognitive alterations, registered in different Family Health Centers.

\section{Methods}

This is a descriptive, cross-sectional study with a quantitative character, carried out in a town located in the central region of the state of São Paulo.

For selection of the research subjects, data was used from the "Care technology for Elderly Persons with cognitive alterations" study undertaken in São Carlos (São Paulo) in 2007. In this study, first of all a survey was carried out of the Family Health Centers in the town, and the number of people registered aged 60 or more was 
identified. Of the 1,578 elderly registered, a probabilistic sample of 755 was evaluated. This data was recorded in the databank of the São Carlos Federal University's (UFSCar) Group for Research into Health and Aging. For the present study, elderly persons whose Mini-Exam for Mental State (MEMS)(15) results indicated they had cognitive alteration were identified through records in this data bank. Considering, however, that data referring to cognitive evaluation had been used in a previous study, which selected its subjects through a sampling procedure, the present study took as its population the total number of elderly persons evaluated in 2007 and who had obtained a MEMS result below the cut-off point according to level of schooling(15). Of the 755 elderly persons who were evaluated, 195 presented results below the MEMS cut-off point and thus constituted the population for the present study. The decision was made to exclude those elderly persons with serious language or comprehension problems so as to avoid possible distortions in the responses due to the cognitive difficulty. Discarding too, those losses caused by death or change of address, the present study evaluated 101 elderly persons.

Because the elderly persons had indications of cognitive alteration, data collection was undertaken through semi-structured interviews with them, under the supervision of those responsible for them, using the following instruments: instrument for socioeconomic characterization; Medical Outcomes Study (MOS), for evaluation of the social support offered to the elderly in question, this being measured by the frequency with which the elderly person has available material, affective, emotional, and informational support, and positive social interaction (according to the responses, one arrives at a final score for each of the dimensions, varying from 20 to 100 points, with a higher score indicating a higher level of social support) ${ }^{(16)}$; the Katz Index, for assessing performance in basic activities of daily living, which involve activities related to self-care such as feeding oneself, washing, dressing, carrying out personal hygiene and maintaining continence ${ }^{(3)}$; the Pfeffer Functional Activities Questionnaire for assessment of performance of instrumental activities of daily living, which include ability to prepare meals, go shopping, use transport, take care of the house, use the telephone, take care of one's finances, take one's medication and remember arrangements, events, family members and holidays ${ }^{(4)}$.
Data collection took place between the months of August and December 2009. Previously-arranged home visits were carried out at the residences of 101 elderly persons. The data was collected after the elderly people concerned and the family members responsible for their care had read and signed the Terms of Free and Informed Consent. It fell to the Family member responsible for caring for the elderly person to confirm the answers referring to socioeconomic characterization, the Katz Index and the Pfeffer Functional Activities Questionnaire. Concerning answers to the Medical Outcomes Study questions, on the other hand, Family members were asked not to interfere, as this involves subjective answers. As elderly persons with serious language or comprehension difficulties had been excluded, the reliability of the answers was assumed, as studies indicate that social support perceived by the elderly is as important as that which is actually received $^{(17)}$.

The data was analyzed through descriptive and correlational statistics. The variables for sex, age range, race, religion, level of schooling, marital status, elderly person's monthly income, family's monthly income, number of people living in the residence, Katz Index, and Pfeffer Functional Activities Questionnaire were correlated with each dimension of social support (material, affective, emotional, informational and of positive social interaction), applying for this the Shapiro-Wilk normal distribution test and the Spearman correlation coefficient, as this is ideal for checking correlation involving non-metric variables.

The recommendations of Resolution 196/96, regulated by the National Health Council, which concerns research involving human beings, were respected. The research project was approved by the University Research Ethics Committee (Process 119/2009) and data collection was also authorized by the city's Municipal Health Department.

\section{Results}

Individual home interviews were carried out with 101 elderly persons registered in Family Health Centers, who had gained results in the Mini Exam for Mental Status below the cut-off point ${ }^{(15)}$ in a previous study. The average age of these elderly persons was 75 , with standard deviation of 8.8 years. A description of the sociodemographic characteristics in percentage terms may be seen in Table 1. 
Table 1 - Percentage description of the elderly persons in the study according to sociodemographic and economic characteristics São Carlos, SP, Brazil, 2010

\begin{tabular}{|c|c|}
\hline Variable & $\%$ \\
\hline \multicolumn{2}{|l|}{ Sex } \\
\hline Female & 71.3 \\
\hline Male & 28.7 \\
\hline \multicolumn{2}{|l|}{ Age range } \\
\hline $60-69$ years & 28.7 \\
\hline $70-79$ years & 41.6 \\
\hline $80-89$ years & 21.8 \\
\hline 90 years or over & 7.9 \\
\hline \multicolumn{2}{|l|}{ Schooling } \\
\hline Illiterate & 34.6 \\
\hline 1 to 3 years of schooling & 33.7 \\
\hline 4 to 7 years of schooling & 25.7 \\
\hline 8 years of schooling & 4.0 \\
\hline 9 to 11 years of schooling & 1.0 \\
\hline 12 years of schooling or more & 1.0 \\
\hline \multicolumn{2}{|l|}{ Marital situation } \\
\hline Married/cohabiting & 38.6 \\
\hline Single & 5.9 \\
\hline Widow/widower & 49.5 \\
\hline Separated/ Divorced & 6.0 \\
\hline \multicolumn{2}{|l|}{ Race } \\
\hline Caucasian & 72.3 \\
\hline Afro-Brazilian & 1.8 \\
\hline Mixed race & 12.9 \\
\hline \multicolumn{2}{|l|}{ Elderly person's monthly income } \\
\hline Up to 1 minimum salary & 64.4 \\
\hline More than 1 minimum salary & 35.6 \\
\hline \multicolumn{2}{|l|}{ Monthly income of family } \\
\hline Less than 1 minimum salary & 16.8 \\
\hline From 1 to 2 minimum salaries & 30.7 \\
\hline More than 2 minimum salaries & 52.5 \\
\hline \multicolumn{2}{|l|}{ Religion } \\
\hline Roman Catholic & 64.4 \\
\hline Pentecostalist & 31.7 \\
\hline Spiritualist & 1.0 \\
\hline Others & 2.9 \\
\hline \multicolumn{2}{|c|}{$\begin{array}{l}N^{\circ} \text { of people living in the residence, including the } \\
\text { elderly person }\end{array}$} \\
\hline 1 person & 11.9 \\
\hline 2 persons & 34.6 \\
\hline 3 persons & 22.8 \\
\hline More than 3 persons & 30.7 \\
\hline \multicolumn{2}{|c|}{ Child from 0 to 14 living with the elderly person } \\
\hline Yes & 19.8 \\
\hline No & 80.2 \\
\hline
\end{tabular}

Of the 101 elderly making up the study, $84.2 \%$ were classified as independent on the Katz Index. Women were in the majority, whether in terms of Independence $(58.4 \%)$, partial independence $(5.9 \%)$, or important dependence $(6.9 \%)$. In relation to age range, it may be seen that the independent elderly persons predominate in all age ranges. Although in the age range 60 to 69 , there were no elderly persons with partial or important dependence, between 70 to 79 years the elderly with important dependence totaled 3.9\%, while between 80 and 89 the number was $1.9 \%$.

All the basic activities of daily living were carried out with higher percentages by the elderly. The activities of bathing $(20.8 \%)$ and dressing (16.8\%) were the activities most-cited by the elderly as requiring help to be carried out.

The performance of the elderly in instrumental activities of daily living, on the other hand, as shown by the Pfeffer Questionnaire, revealed that $52.5 \%$ of the elderly were independent and that $46.5 \%$ were dependent for these activities.

Both among the male and female elderly, a greater number of independent individuals could be observed ( $15.8 \%$ and $36.3 \%$, respectively). In the age ranges of 60 to 69 years $(21.8 \%)$ and 70 to 79 years $(23.8 \%)$ there was a greater number of elderly who were independent for instrumental activities of daily living, while between 80 and 89 years $(16.8 \%)$, and 90 years or over $(5.9 \%)$, dependent elderly predominated for these activities, demonstrating the relationship between increase in age and functional loss.

In relation to carrying out instrumental activities of daily living, the only activities in which the percentage of dependence was greater were ability to take care of one's own money (52.7\%) and ability to remember arrangements, family events and holidays (58.3\%).

In relation to social support the average achieved by the 101 elderly persons, considering the five dimensions of support, was 74.43. Analyzing each dimension separately, one may observe a good level of social support in the material and affective dimensions, which indicates that the availability of material resources such as money or help with domestic activities, and physical demonstrations of affection such as hugs or kisses, are satisfactory for these elderly persons. The dimensions of emotional, informational and positive social interaction support on the other hand show a lower level of support, as it is below the total average.

The application of Spearman's Correlation Coefficient, considering a level of significance of $5 \%$, demonstrates the existence of a significant correlation between the dimension of emotional support and the Katz Index. 
Table 2 - Spearman's Correlation Coefficients for the different dimensions and the Katz variable São Carlos, SP, Brazil, 2010

\begin{tabular}{lcc}
\hline \multicolumn{1}{c}{ Correlated variables } & $\begin{array}{c}\text { Spearman's Correlation } \\
\text { Coefficient }\end{array}$ & P-value \\
\hline Material Support \& Katz & -0.00 & 0.96 \\
Affective Support \& Katz & 0.00 & 0.98 \\
Emotional Support \& Katz & -0.21 & 0.03 \\
Informational Support \& Katz & -0.00 & 0.97 \\
Positive Social Interaction & -0.08 & 0.41 \\
\& Katz & & \\
\hline
\end{tabular}

Statistically-significant correlations were not found between material support, affective support, information support and support from positive social interaction and the Katz Index variable. Also observed was the absence of correlation between all of the dimensions of social support and the results from the Pfeffer Questionnaire.

\section{Discussion}

The majority of the elderly people of this study reported high levels of perceived social support, confirming the data from previous research ${ }^{(16,18)}$. The perception of having good social relationships with family, and that these relationships can help in times of need, is an important factor in maintaining quality of life for the elderly(12).

The predominance of illiterates among the elderly evaluated is a relevant sociodemographic factor, as the chance of being moderately/seriously dependent is four to five times greater among the elderly with a low level of schooling(19).

The predominance of widows (46.15\%), followed by married $(34.19 \%)$ can be explained by the fact that the elderly women make up the majority of participants in this study, which may be attributed both to the lower life expectancy of the men, or to the greater frequency with which men re-marry after being widowed and their greater tendency to marry younger women ${ }^{(20)}$.

In relation to the evaluation of performance in basic and instrumental activities of daily living, even taking into account that the incidence of functional incapacity is similar between the sexes, its prevalence is generally higher among the women. This may be explained by the fact that women live longer than men, that there is a greater prevalence of non-fatal incapacitating conditions among the women (osteoporosis, osteo-arthritis, and depression, for example), and women's greater ability to report a higher number of health conditions compared to men of the same age range ${ }^{(21)}$.

In relation to social support, the dimension of emotional support, which has to do with receiving demonstrations of trust, empathy, tenderness, love, listening and interest; the dimension of information support, which has to do with availability of advice, suggestions, and information; and finally, the dimension of positive social interaction, which refers to having somebody with whom to relax and do pleasant things, all need to be stimulated, such that the levels of support in these dimensions may satisfy the needs of the elderly persons assessed in the most effective way.

The importance for the elderly of the correlation found between the results of the Katz Index and the dimension of emotional support may be observed in the Established Populations for the Epidemiological Study of the Elderly (EPESE) study, carried out in East Boston, New Haven and County Durham, which evaluated the emotional and instrumental (or material) support offered to the elderly, and concluded that deficits in this last are related to an increase in risk of physical incapacity among men, and that emotional support has a close link with the reduction of incapacities ${ }^{(22)}$. This finding is corroborated by the fact that emotional support has a protective effect, and that contacts who offer this support can lead the elderly concerned to develop feelings of commitment and social interaction, bestowing greater meaning on their lives ${ }^{(23)}$.

It may be observed that more than the effect of a single dimension of support, social support as a whole relates to functional capacity ${ }^{(12,14)}$. A study carried out in Denmark with 1396 elderly persons aimed to establish the social relationships as a determinant for elderly incapacity, and obtained results which demonstrate that the diversity of social relationships and participation in social activities are key factors in maintaining functionality in elderly persons aged 75 or over(24). For the same purpose, a systematic review undertaken with the databases MEDLINE, PsycINFO, SOCA, and EMBASE between 1985 and 1997, concluded that having few social contacts is related to the development of incapacity and reduction in physical function ${ }^{(14)}$.

Besides the relationship between social support and functionality, it is extremely important to consider the peculiarities of the population studied, in terms of cognitive alterations, as social skills include cognitive components (of perception and information processing) and social relationships protect against the decline of these functions ${ }^{(25)}$.

\section{Conclusion}

Independent elderly persons predominated as much for basic activities of daily living as for instrumental. Concerning social support, a better level of material 
and affective support was observed in comparison to the other dimensions of support. The results also demonstrate the existence of a significant correlation between the dimension of emotional support and the Katz Index. This being the case, Nursing can act by implementing strategies which stimulate the offering of emotional support to dependent elderly persons.

Despite the study's limitations, (little statistical deepening in the analysis of the data and the sample size) it is extremely important to consider the influence of social support in the functionality of the elderly with cognitive alterations, so as to better guide health actions for this population. Because the elderly are a priority for the Unified Health System* in the national health policy, and because functionality is the paradigm for aging, the establishment of holistic care pathways which ensure the maintenance of functional capacity in the elderly is crucial.

Considering the scarcity of Brazilian studies on this theme, and recognizing the relevancy of the paradigm of functionality in the elderly, it is essential for Nursing to make this knowledge their own, as elderly people with cognitive alterations - and more than this, with difficulty in carrying out activities of daily living - require a great deal of care from health care professionals. Related to this, recognizing the relationship between social support and functionality in the elderly with cognitive alterations is extremely important for the appropriate planning and implementing of a care plan which ensures the use of social support as a strategy which benefits the health of the elderly. By promoting the building of networks which offer social support to elderly people with cognitive alterations, nurses can contribute to the improvement of functional and cognitive capacity in the elderly people concerned. Once incorporated into nursing practice, this knowledge will contribute to the consolidation of the role of the nurse in gerontological nursing.

\section{References}

1. Alves LC, Leimann BCQ, Vasconcelos MEL, Carvalho MS, Vasconcelos AGG, Fonseca TCO, et al. A influência das doenças crônicas na capacidade funcional dos idosos do Município de São Paulo, Brasil. Cad Saúde Pública. Aug 2007;23(8):1924-30.

2. Hwang RI, Lim JY, Lee YW. A Comparison of the factors influencing the life satisfaction of the elderly according to their cognitive impairment level. J Korean Acad Nurs. Oct $2009 ; 39(5): 622-31$.
3. Lino VTS, Pereira SEM, Camacho LAB, Ribeiro ST Filho, Buksman S. Adaptação transcultural da Escala de Independência em Atividades da Vida Diária (Escala de Katz). Cad Saúde Pública. jan 2008;24(1):103-12.

4. Pfeffer RI. Measurement of functional activities in older adults in the community. J Gerontol. 1982;37(1):323-9. 5. Lebrão ML, Laurenti RL. Condições de saúde. In: Lebrão ML, Duarte YAO. SABE - Saúde, Bem-estar e Envelhecimento - O Projeto Sabe no município de São Paulo: uma abordagem inicial. Brasília (DF): Organização Pan - Americana da Saúde; 2003. p. 73-91.

6. Habib ALCM, Caldas CP. O trabalho de consciência corporal humanizado em idosos com transtorno cognitivo. Rev Bras Geriatr Gerontol. jan-abr 2008;11(1); [acesso 24 abr 2009] Disponível em: http://www.unati.uerj. $\mathrm{br} / \mathrm{tse} /$ scielo.php?script $=$ sci_arttext\&pid $=\mathrm{S} 1809$ 98232008000100011\&lng=pt\&nrm=iso

7. Neri AL. Envelhecimento cognitivo. In: Freitas EV, et al. Tratado de Geriatria e Gerontologia. Rio de Janeiro: Guanabara Koogan; 2006. p. 1236-51.

8. Troncoso M, Alvarez C, Sepúlveda R. Redes sociales, salud mental y esquizofrenia: una revision del tema. Rev Psiquiatria (Santiago de Chile). jun-dez 1995;12(34):163-72.

9. Bocchi SCM, Angelo M. Entre a liberdade e a reclusão: o apoio social como componente da qualidade de vida do binômio cuidador familiar-pessoa dependente. Rev. Latino-Am. Enfermagem. jan-fev 2008;16(1); [acesso 24 abr 2009] Disponível em: http://www.scielo.br/pdf/ rlae/v16n1/pt_02.pdf

10. Ostergren PO et al. Social network, social support and acute chest complaints among young and middleaged patients in an Emergency Department: a casecontrol study. Soc Scienc Med. 1991;33(33):257-67

11. Ramos MP. Apoio social e saúde entre os idosos. Sociologias. jan-jun 2002;4(7):156-75.

12. Golden J, Conroy RM, Lawlor BA. Social support network structure in older people: Underlying dimensions and association with psychological and physical health Psychol Health Med. 2009;14(3):280-90.

13. Bennett DA, Schneider JA, Tang $Y$, Arnold SE, Wilson RS. The effect of social networks on the relation between Alzheimer's disease pathology and level of cognitive function in old people: a longitudinal cohort study. Lancet Neurol. 2006;5(1):406-12.

14. Stuck AE, Walthert JM, Nikolaus T, Büla CJ, Hohmann C, Beck JC. Risck factors for functional status decline in community-living elderly people: a systematic review. Soc Sci Med. 1999;48(1):445-69.

* Unified Health System: the Brazilian State Health Service. Translator's Note. 
15. Nitrini R, Caramelli R, Bottino P, Campos CM de, Damasceno BP, Brucki SMD, et al. Diagnóstico de doença de Alzheimer no Brasil: critérios diagnósticos e exames complementares. Recomendações do Departamento Científico de Neurologia cognitiva e do Envelhecimento da Academia Brasileira de Neurologia. Arq. Neuropsiquiatr. 2005;63(3-A):713-27.

16. Griep RH, ChorD, Faerstein E, Werneck GL, Lopes CS. Validade de constructo de escala de apoio social do Medical Outcomes Study adaptada para o português no Estudo Pró-Saúde. Cad Saúde Pública. mai-jun 2005;21(3):703-14.

17. Guedea MTD, Albuquerque FJB de, Tróccoli BT, Vera Noriega JA, Seabra MAB, Domínguez Guedea RL. . Relação do bem-estar subjetivo, estratégias de enfrentamento e apoio social em idosos. Psicol.Reflex Crit. 2006;19(2):301-8.

18. Dupertuis LL, Aldwin CM, Bossé R. Does the Source of Support Matter for Different Health Outcomes?: Findings from the Normative Aging Study. J Aging Health. 2001;13(1):494-510.

19. Reis LA, Torres GV, Silva JPA, Sampaio LS, Reis

LA. Perfil Epidemiologico de idosos institucionalizados no Municipio de Jequie/BA. Rev Enferm Atual. 2008;46(1):19-23.

20. Lima-Costa MF, Uchoa E, Peixoto SV, Giacomin KC. Estudo de base populacional dos fatores associados a incapacidade funcional entre idosos na regiao metropolitana de Belo Horizonte, Minas Gerais, Brasil. Cad Saúde Publica. 2008;24(6):13-20.

21. Murtagh KN, Hubert HB. Gender differences in physical disability among an elderly cohort. Am J Public Health. 2004;94(1):1406-11.

22. Seemam TE, Bruce ML, McAvay GJ. Social network characteristics and onset of ADL disability: MacArthur Studies of successful aging. J Gerontol: Soc. Scienc. 1996;51(b):191-200.

23. Mendes CFL, Glass TA, Beckett LA, Seeman TE, Evans DA, Berkman LF. Social networks and disability transitions across eight intervals of yearly data in the New Haven EPESE. J Gerontol B Psychol Sci Soc Sci. may 1999;54(3):162-72.

24. Avlund K, Lund R, Holstein BE, Due P. Social relations as determinant of onset of disability in aging. Arch Gerontol Geriatr. 2004 Jan-Feb;38(1):85-99.

25. Fratiglioni L, Wang $H X$, Ericsson $K$, Maytan $M$, Winblad $B$. Influence of social network on occurrence of dementia: a community-based longitudinal study.

Lancet. 2000;355:1315-9. 